\title{
Agricultural Revitalization Through Extension Knowledge to the Community Regarding the Socio-Economy of Agriculture
}

\author{
Mbemba Garenba \\ University of Kamina, DR Congo
}

\begin{abstract}
This article discusses the revitalization of agriculture through the knowledge of the extension agents to the community about the socioeconomic of agriculture. The interesting thing is that the potential of each region to develop agribusiness is very different. Therefore, to develop extension services that support the development of agribusiness, it is necessary to examine carefully the potential of each region. So that the diversity of extension materials must be made possible by innovation. Agricultural extension is expected to be the central point of agricultural development. However, in agricultural extension it must be remembered that extension is a form of intervention against farmers. Progressive and effective agricultural extension workers must be supported and collaborate closely with the Agricultural Research Institute including socio-economic research on agricultural extension which simultaneously conducts monitoring and evaluation of agricultural extension continuously. In disseminating information, the extension worker must carry out a reciprocal process, namely conveying information in the form of researchers' findings to farmers. Sustainable agricultural development really requires the support of strong agricultural technology and socioeconomic research results. Without this, agricultural development will stagnate. Therefore, people's participation in planting knowledge needs to be increased.
\end{abstract}

Keywords: Agricultural Revitalization, Extension Knowledge, Socio-economy

\section{Introduction}

Revitalization of Agricultural Extension is an effort to position, act and function as well as restructure agricultural extension in order to realize a unity of understanding, unity of corp and unity of policy direction. The successful implementation of this revitalization requires support from various parties, including the central government, local governments, and the community as agricultural entrepreneurs.

The revitalization program is focused on several sub-programs, namely structuring agricultural extension institutions, increasing the quantity and quality of agricultural extension agents, improving farmer institutions and leadership, improving agricultural extension delivery systems, and developing cooperation between agricultural extension systems and agribusiness (Swanson, 2008; Larsen et al 2009).

Agricultural dynamics that also move along with global developments require field extension workers to have a function in at least three things, namely technology transfer, facilitation and advisory work. To support these functions, field agricultural extension workers should also master and utilize information and communication technology. 
Extension themes have also shifted not only to increasing production but adjusting to other global issues, for example how to prepare farmers for farming to overcome the problems of global climate change and global trade. Farmers need to be introduced to production facilities that have high adaptability to climate shocks. In addition, farming techniques that are environmentally friendly, water efficient and resistant to high temperature stress are likely to be an important theme for future agricultural extension.

\section{Revitalization of Extension and Social-economic Knowledge Sharing}

As stated at the beginning of the paper, revitalizing agricultural extension agents is intended as a follow-up to agricultural revitalization. However, it should also be remembered that the agricultural revitalization policies that have been launched by the government have not been matched with and supported by policies in other sectors. The issue of land availability for farmers has not been accommodated as expected. It is proven by the many cases of seizure of agricultural land against the interests of capital. The availability of agricultural land is also faced with the problem of land conversion to settlement or use in other business sectors.

Agricultural extension is expected to be the central point of agricultural development. However, in agricultural extension it must be remembered that extension is a form of intervention against farmers. Intervention from outside coupled with the provision of assistance services and facilities is indeed necessary, but if a misstep can become a heavy burden for those who help, in the form of dependence on those who help, farmers lose part of their independence, and lose their sense of social responsibility unwillingness pay credit, etc. Therefore it is necessary to develop an appropriate strategy so that the intervention does not become a burden for those who help.

Farmers, especially in rice and agricultural commodity areas, feel and judge that they are the object of agricultural development projects, which according to them are more concerned with achieving national or regional production targets, and administrative targets for budget use. Farmers feel they want to play a more role in agricultural development and call for more serious empowerment of extension services so that it is conducive to the development of farmer independence institutional empowerment at the farmer level (Leeuwis, 2013). The reality shows that farmers are generally not only producers of agricultural commodities, but also agribusiness actors. In the future, his status as an agribusiness must be more empowered. If this is done properly and well, then this will really make our farmers increase their independence and at the same time ensure national food security.

The potential of each region to develop agribusiness is very different. Therefore, to develop extension services that support the development of agribusiness, it is necessary to examine carefully the potential of each region. So that the diversity of extension materials must be made possible by innovation.

The vision and mission of agricultural extension should be made by placing farmers and farm businesses at the center. Agricultural extension is carried out with a more humanistic approach, namely seeing farmers as potential human beings, who are valued for their ability to develop towards independence. It is necessary to reorient the vision and mission in the extension institution to return to the extension unit itself, namely the development of farmer empowerment, so that farmers are better able to improve the welfare of themselves, their families and communities independently and are not subordinated by the interests of other parties in developing their farming businesses. The implementation of agricultural extension needs to be more professional, which, among other things, requires reorientation: from an 
agency approach to developing the quality of individual extension work; from top down to bottom up approach; from vertical to horizontal work hierarchy; from instructive to participatory and dialogical approaches and from linear work systems to network work systems.

Farmers' participation in evaluating the results of food crop farming activities did not receive proper attention in the context of farmer participation in evaluation activities which was relatively better, although still inadequate. From year to year the movement of people planting trees continues to increase. We are grateful that community support and participation is so high. Including this activity arises from community suggestions. Community participation is community participation in the process of identifying problems and potentials that exist in the community, selecting and making decisions about alternative solutions to address problems, implementing efforts to overcome problems, and community involvement. Community participation in planting knowledge needs to be increased.

Increasing the knowledge / expertise of the extension agents needs to be developed in such a way that it is conducive to self-development of self-potential, which is to foster an independent attitude of the instructor in developing himself as an increasingly professional extension (Norgaard, 1984; Higgins, 2002). Agricultural extension is not only limited to transfer of technology, but it is time to turn to farmer participation and the biggest portion of any agricultural policy is to build farmers' abilities increasing leadership abilities, quality of life and empowering farmers (Skogstad, 2008; Lamine, 2011).

Progressive and effective agricultural extension workers must be supported and collaborate closely with the Agricultural Research Institute (including socio-economic researchagricultural extension) which simultaneously conducts monitoring and evaluation of agricultural extension on an ongoing basis. In disseminating information, the extension worker must carry out a reciprocal process, namely conveying information in the form of researchers' findings to farmers. Delivering the results of the application of technology and the problems faced by farmers to researchers.

Agricultural extension is not only related to the production process, but what modern agriculture needs is extension that covers all aspects of agribusiness, namely production, post-harvest, processing, marketing, price and others (Keding et al., 2013). The existence of the Agricultural Technology Research Institute which has a clear existence at this time needs to be studied in terms of its functional relation with the agricultural extension system that will be organized. It should be realized that sustainable agricultural development really requires the support of strong agricultural technological and socio-economic research results. Without it, agricultural development will stagnate. Apart from that, community participation also supports the development of farmers' knowledge.

\section{Conclusion}

Revitalization of extension workers and agricultural extension is absolutely necessary to support agricultural development. The revitalization of agricultural extension needs to be balanced with the revitalization of agriculture as a whole and also supported by policies in other sectors such as agrarian reform and laws related to the agricultural sector. Agricultural extension as a form of intervention for farmers needs to be made with the aim of fostering farmer independence. Therefore, the implementation of extension is carried out with the philosophy of helping people to be able to help themselves, including their families and communities through an educational effort that is democratic and has insight into the 
development of farmer independence. Extension objectives need to be formulated from a farmer's perspective in order to further motivate farmers. Although there is a close relationship between Agricultural Extension and Food Production Enhancement Programs, they should not be confused. Whether there is a Production Enhancement Program or Project, agricultural extension must continue to be institutionalized, systematic and sustainable in the midst of the community.

\section{References}

Higgins, V. (2002). Constructing reform: Economic expertise and the governing of agricultural change in Australia. Nova Publishers.

Keding, G. B., Schneider, K., \& Jordan, I. (2013). Production and processing of foods as core aspects of nutrition-sensitive agriculture and sustainable diets. Food security, 5(6), 825-846.

Lamine, C. (2011). Transition pathways towards a robust ecologization of agriculture and the need for system redesign. Cases from organic farming and IPM. Journal of rural studies, 27(2), 209-219.

Larsen, K., Kim, R., \& Theus, F. (2009). Agribusiness and innovation systems in Africa. The World Bank.

Leeuwis, C. (2013). Communication for rural innovation: rethinking agricultural extension. John Wiley \& Sons.

Norgaard, R. B. (1984). Traditional agricultural knowledge: past performance, future prospects, and institutional implications. American Journal of Agricultural Economics, 66(5), 874-878.

Skogstad, G. (2008). Internationalization and Canadian agriculture: Policy and governing paradigms (Vol. 30). University of Toronto Press.

Swanson, B. E. (2008). Global review of good agricultural extension and advisory service practices (p. 82). Rome: Food and Agriculture Organization of the United Nations. 